\title{
The Global Value of Mencius’s Ideas on Moral Feeling and Reason: Reinterpreting the Feeling of Compassion From the Perspective of the Philosophy of Emotion
}

\author{
Liu Yuedi \\ Chinese Academy of Social Sciences, Beijing, China
}

\begin{abstract}
Amid the recent global upsurge of studies on the philosophy of emotion, a reinterpretation of traditional Confucian philosophy, especially Mencius’s ideas on the siduan (Four Original Sources) of morality, may shed new light on the subject in comparative philosophy. This paper probes the structure of moral feeling and reason described by Mencius's from five perspectives: (1) In view of the relationship between feeling and reason, is it better to use the expression "siduan" or the expression "sixin (Four Heart-minds)"? (2) In view of dispositional feeling, what are the four original sources? (3) In view of moral feeling, what are the structural order of the four sources and the corresponding procedure of reasoning of four heart-minds of Humanity? (4) In view of positive feeling, how does moral feeling grow out of the goodness of human nature? (5) What is the global value of Mencius's ideas on human moral feeling? The author concludes that Mencius's thought on moral feeing has a global value and cross-cultural significance, and that Chinese wisdom is more than regional but universally applicable. The structure of moral feeling and reason that Mencius identified is in accordance with the principles of zhiliang (grasping the two poles of the beginning and the end) and yongzhong (emloying the middle). The principles of zhiliang and yongzhong are true universal wisdoms of Confucianism, which should be rekindled today. From a practical point of view, "the Way begins from moral feelings,” and Confucius and Yan Hui’s seeking the simple, virtuous life is an ideal model of emotional well-being.
\end{abstract}

Keywords: philosophy of emotion, four original sources, compassion, structure of moral feeling and reason, global value

Mencius’s ideas on moral feeling are reflected in his concept of siduan 四端, literally meaning the “four original sources.” Mencius stated: “The feeling of compassion (ceyin zhi xin 恻隐之心) is the original source of humanity (ren 仁); the feeling of shame and dislike (xiuwu zhi xin 差恶之心), the original source of righteousness (yi 义); the feeling of reverence and respect (cirang zhi xin 辞让之心), the original source of ritual propriety (li 礼); the feeling of right and wrong (shifei zhi xin 是非之心), the original source of wisdom (zhi 智)” (Mencius, 2A: 6). ${ }^{1}$ These concepts have already influenced Western ideas of virtue ethics and can

Liu Yuedi, Doctor of Philosophy, Professor, Institute of Philosophy, Chinese Academy of Social Sciences.

Correspondence concerning this article should be addressed to Liu Yuedi, 5 Jianguo Men Nei Road, Beijing, 100732.

${ }^{1}$ Bibliography of Cited Translations: James Legge trans. The Works of Mencius. Beijing: Foreign Language Teaching and Research Press. 2011; Bryan W. Van Norden trans. Mengzi: With Selections from Traditional Commentaries. Indianapolis: Hackett Publishing. 2008. 
further be related to some major issues in the philosophy of emotion: Does moral feeling contain reason? Which feelings are experiences of merely animal nature? What is the internal procedure of moral feelings? What role do positive feelings play in morality? Therefore, a reexamination of Mencius's thought on moral feelings and their possible interpretations in modern terms will be of global value in the present era.

\section{Moral Feeling vs. Reason: Four Original Sources or Four Heart-Minds}

Mencius describes the four human feelings-compassion, shame and dislike, reverence and respect, and right and wrong—collectively as the siduan 四端 or sixin 四心. In the sense of origins, they are called the siduan, the Four Original Sources. In terms of their location and expression, they are called the sixin, the Four Heart-Minds. Mencius claims that these are the sources of the Four Norms of Morality, which he identifies as humanity, righteousness, propriety, and wisdom. However, one matter is neglected: Are these four moral feelings, properly speaking, some untutored emotional beginnings (duan) or do they represent the rich feeling and cognition of the human heart-mind (xin)? Usually there is no need to distinguish between full expressions and their causes. Still, the two are definitely not the same. Duan 端 (the original source of morality) is emotionally based while xin 心 (the heart-mind) is reason-based. These terms certainly imply the blended consequences of both feeling and reason, but when we speak of someone as having a given "mind," we are speaking of him as having rational consciousness functioning behind that "mind."

The duan of human virtue concerns the emotional source of virtue, but xin deals with the rational consciousness or reason, with rational cognition based on principles. This dual aspect of virtue involves the relationship between feeling and reason. In classical philosophy of the continental tradition, feeling and reason are discussed in separation and often as antithetical. In this dichotomy, feeling is identified as emotion and considered as the irrational aspect of human mind. However, the current philosophy of emotion and its scientific research try to prove or demonstrate the participation of reason in the operation of emotions. If reason, strictly speaking, is only defined as mental operation of concepts to formulate plans and make decisions in order to cope with new situations, then, in this sense, all emotions are rational. Otherwise, if the emotions are only partly rational or reason-based, then reason in this sense becomes an evaluative concept, for "it presupposes rationality in the first sense and evaluates our logic and our strategies in terms of their consistency and effectiveness." ${ }^{2}$ This means that there is indeed the presence of reason in the operation of emotions, and reason of this sort, as a strategic activity in a certain situation, actually entails evaluation. Mencius's concept of siduan exactly fits this structure of feeling/emotion and reason (qingli jiegou 情理结构). ${ }^{3}$

To be sure, Mencius's doctrine of siduan reveals a certain ethical strategy, and each of the siduan contains an evaluative rationality. However, the internal ingredients of the feeling-reason structure vary from one faculty to another. In the feeling of compassion, emotion plays a more important role, but its importance diminishes along the sequence from shame and dislike, to reverence and respect, to distinguish between right and wrong; conversely, in the feeling of right and wrong, reason is more salient but it is less so in reverence and respect, shame and dislike, and least in compassion. By this order of enumeration, Mencius demonstrates the different weights of emotion and reason respectively in humanity, righteousness, propriety, and wisdom, which

\footnotetext{
${ }^{2}$ Robert C. Solomon, Passions: Emotions and the Meaning of Life (Indianapolis: Hackett Publishing Company, 1993$), 188$.

${ }^{3}$ Qingli jiegou is quoted from Li Zehou's idea. See Li Zehou and Liu Yuedi, “Guanyu 'Qing ben ti' de zhongguo zhexue duihua” 关于 “情本体” 的中国哲学对话 [A Philosophical Dialog on the ‘Ontology of Emotion'], Journal of Literature, History and Philosophy 文史哲, no. 3 (2014).
} 
he says develop from the respective siduan. Humanity is more emotionally oriented, wisdom is more reason-oriented; as righteousness is closer to humanity (humanity-righteousness), it is more emotion-inclined, whereas propriety, which is more closely related to wisdom (propriety-wisdom), is more inclined to reason.

Let us examine the first and the last siduan. Is the feeling of compassion purely emotional? Mencius illustrates his point in this passage: "If one suddenly sees a child who is to fall into a well, one will, without exception, experience a sense of alarm and distress (怵惕恻隐)” (Mencius, 2A: 6). Does this emotional experience of "alarm and distress" (or alarm and compassion) correspond to "sympathy" in Western philosophy? It seems doubtful. Compassion could be a kind of sympathy, within which there must be pity, but it also contains the meanings of alarm and distress, warning and fearing, as can be seen in the statement: "Cautiously and fearfully, day and night, one cultivates one’s moral character and disciplines one’s behavior” (日夜怵惕, 修身正行; History of the Former Han Dynasty, "Biography of Liu Chang”). One must be as cautious in cultivating one's mind. The point of Mencius's illustration is that, in such a situation of ethical concern, people who anticipate the child's fall will not think of their relationship with the child's parents, nor do they intend to win praises from friends or neighbors afterwards, and least worry about being disturbed by the child's cry; instead, their moral instinct of empathy takes hold of them, and without a second thought they act to save the child.

One's love for parents and expectance of the neighbors' praises are often considered as rational instances of emotion, but an act of compassion seems to be at the mercy of emotions. Frans de Waal observes that Mencius uses the spontaneity of moral feeling (e.g. sympathy) to overcome the possible dichotomy between a Freudian motive and an experienced motive, that is, between a manifest motive and an experienced motive, and to overcome the possibility of misunderstanding. ${ }^{4}$ In terms of the sub-consciousness and consciousness, the expressed or manifest motive is the duan, and the experienced motive is the xin. In fact, Mencius does not clearly distinguish the two, as if one immediately follows after the other. Meanwhile, there are no gaps between the incipient duan, and the conscious xin, as well as between them and ethical acts. The key question is: how is it possible that an ethical response starts from duan to xin, and then proceeds to action? There is, first of all, the unconscious evaluation in the operation of emotion in the situation, recognizing that it is correct to save the child or that it is wrong not to save the child—a quasi-rational decision-making. Beyond that split second when the feeling of compassion is activated, its rationality is so subtly employed that it is nearly imperceptible.

Next let us examine the feeling of right and wrong. This mental experience is not a purely rational judgment like the proposition, "this is a flower." Rather, it is a judgment blended with emotions, a kind of moral judgment in which behavior is justified in terms of emotion and reason. It resembles the aesthetic judgment in the statement, "The flower is beautiful." However, aesthetic judgment is more sensuous and evaluative while moral judgment is more tied to reason, although the appeal of emotion still has a potential role within moral judgment. Then what kind of an emotion-reason structure pertains to the feeling of right and wrong?

This involves the relationship between emotion and moral reasoning, which is particularly prominent in the feeling of right and wrong. Donald J. Munro has explained that in this regard Confucians could find common ground with evolutionary biologists and psychologists. He says,

\footnotetext{
${ }^{4}$ Frans de Waal, Primates and Philosophers: How Morality Evolved, trans. Zhao Qianli, (Shanghai: Shanghai Science and Technology Education Press, 2013), 54.
} 
It is that moral concepts owe much more to innate social emotions than Western psychologists or ethicists have traditionally recognized. The Confucian position is illustrated in the description of one of the "four heart-minds" identified by Mencius. It is shifei zhixin (the feeling of right and wrong). This phrase means that this heart-mind can know (a cognitive awareness) right and wrong, and, simultaneously, that it will approve of right and disapprove of wrong (the emotional acceptance or rejection). These emotions are motives for action. Hence, Confucians developed the principle of "the unity of knowledge and action," because emotionally charged knowledge motivated action. ${ }^{5}$

This means that knowing what is right and wrong (by rational reasoning) happens almost simultaneously with the feeling of approval of the right (emotional acceptance) or disapproval of the wrong (emotional rejection), and instantaneously they result in moral acts.

Thus, siduan, Four Original Sources of morality, which Mencius talks about, also constitute sixin, the Four Heart-minds of humanity, in their rational aspects. Mencius's xin is not only the dwelling place of virtue but also the cognitive mind, making moral judgments and weighing ethical importance. As Mencius explains, "By weighing, we know which things are light, and which things are heavy. By measuring, we know which things are long, and which things are short. This is true of all things, it is particular true of the heart-mind." (Mencius, 1A: 7). When emotive duan converges with cognitive xin, there is unity of feeling and reason. In Mencius's belief, feeling and reason are one and the same wholeness in itself.

\section{Animal Emotions: Where the Four Sources of Morality Are Located?}

Munro's view represents the new direction of present Confucian studies and physiological research, which is worth probing for its merits and demerits. According to ethologist and biologist Frans de Waal, Mencius's view has proved to be in concordance with scientific principles, in that the kind of sympathy Mencius discussed is also shared by non-human primates. Still, the question of whether human nature is virtuous or evil can only be answered with a judgment of probability.

The scientist says,

I could not agree more. Evolution has produced species that follow genuinely cooperative impulses. I don't know if people are, deep down, good or evil, but to believe that each and every move is selfishly calculated, while being hidden from others (and often from ourselves), seems to grossly overestimate human intellectual power, let alone those of other animals. ${ }^{6}$

In the kingdom of non-human animals, such cases are commonplace. For example, non-human animals are found to comfort their frustrated fellows or protect other members of the group from being attacked. There also exists a rich literature on human empathy and sympathy that, generally, agrees with Mencius’s view_ “an impulse of sympathy comes first and rationalizations occur later., ${ }^{7}$

However, Frans de Waal's scientific conclusion is based on a misinterpretation of Mencius. First, he utterly ignores the difference between humans and non-human animals. But the difference is just the cornerstone of Mencius's argument. Second, he only discusses compassion as one of the original sources of morality, while Mencius's view is more comprehensive and inclusive. Third, he views emotion to be independent of reason, prioritizing emotion to reason, but he ignores Mencius's structure of feeling and reason.

This brings us to the question of animal emotion. What are the emotions that are shared by both humans and non-human animals? And what emotions are unique to and only of humans? We could begin discussion on

${ }^{5}$ Donald J. Munro, A Chinese Ethics for the New Century (Hong Kong: The Chinese University Press, 2005), 52-53.

${ }^{6}$ Frans de Waal, Primates and Philosophers: How Morality Evolved, 55.

${ }^{7}$ Ibid. 
these issues with Mencius's siduan and sixin. The feeling of compassion for members of one's own kind is commonly found in non-human animals as well as humans, but do all non-human animals have the capacity for feelings of shame and dislike? Probably not. Non-human animals do not possess the capacity for senses of reverence and respect and perhaps, those of right and wrong, either. In spite of many zoologists who go as far as to think that primates have moral associations, and even if we concede to the truth of this view, non-human animals are incapable of making moral judgment and cannot make moral distinction between right and wrong even though they have consciousness and senses. Though philosophers like Munro and scientists like de Waal try to link the thought of Mencius to the discoveries of modern biology, Mencius's intention is to distinguish between humans and non-human animals. This distinction is quite distant from current views of modern biology (including various forms of social biology).

Mencius believes that externally humans are distinct from non-human animals in that humans are aware of morality:

Humans are human because they have norms and moral ideas. [Otherwise], if humans desired only that they are well fed, warmly clad, and comfortably lodged while not being not educated and cultivated, then they would be little different from non-human animals. Ancient sages worried about the human situation, and thus had appointed Xie 契 to be the Minister of Instruction, and to teach the people ethics. (Mencius, 3A: 4)

Internally the distinction lies in the presence or absence of humanity and righteousness in the subject:

The distinction between humans and non-human animals is small. The mass thus ignores it, but authentic persons take it seriously. Shun knew the laws that govern things, and understood ordinary human situation and feeling. He followed humanity and righteousness as norms and standards, not treat them as some political strategy. (Mencius, 4B: 47)

Though Mencius acknowledges the subtle distinction between humans and non-human animals, which is quite close to the current biological conclusion, he also emphasizes the distinction between a person's inherent humanity and righteousness and external culture and education in ethical human relations. Mencius does not stress the biological roots of morality but attends to the instruction of humanity and righteousness.

In contrast to most of the later Confucians, especially Neo-Confucianism of the Song and Ming dynasties, Mencius's ethics is exactly characteristic of this biological salience:

Mencius's view is primarily biological in that it does not make the body or the biological needs superficial and frivolous as biological thoughts typically hold, but it is concerned about the interdependence of various parts among humans, the internal sensory organs within humans, the natural phenomenon of growth, development and maturity, and the natural and social contexts needed for promoting the development. It is biological. ${ }^{8}$

This judgment is evidentially correct. Mencius draws many comparisons between moral development and biological growth. If we hope to find a match between Chinese philosophy and modern biology, Gaozi's (ca. 420-350 B.C.) view seems more appropriate, though it is criticized by Mencius: "The philosopher Gaozi said, 'Human nature is akin to qi-willow, and righteousness and reason is akin to a cup or a bowl. To make human nature conform to humanity and righteousness is akin to making cups and bowls from qi-willow'” (Mencius, 6A: 1).

\footnotetext{
${ }^{8}$ Hua Airen, “Zai mengzi zhong rende benxing yu shengwuxue de benxing” 在《孟子》中人的本性与生物学的本性 [Human Nature and Biological Instincts in Mencius], in Mencius’ Learning of Mental-Nature 孟子的心性哲学, comp. James Behuniak Jr. and Roger T. Ames, trans. Liang Xi, (Beijing: China Social Sciences Press, 2005), 233.
} 
More importantly, Mencius establishes the feeling of compassion as the root or locus of all moral virtues. Humanity, righteousness, propriety, and wisdom come respectively from the Four Sources (feelings) of compassion, shame and dislike, reverence and respect, and right and wrong. However, these four feelings are not parallel or equal in their contribution to the virtues. Of the four feelings as instigators of virtue, there is the original of the originals or the beginning of the beginnings. This is the feeling of compassion. Compassion is the first and foremost primary source of siduan, and it is the original source of the feelings of shame and dislike, of reverence and respect, of right and wrong. Mencius identifies compassion a special kind of sympathy, as the ultimate source of morality, and thus it seems reasonable to consider Mencius's ethics as a kind of sentimentalist ethics.

Today, sentimentalism has seen a revival in studies of ethics. However, it has undergone different phases of development. The study of emotion, in terms of the relationship between emotion and reason, can be classified into four models. In the traditional rationalist model, reason first affects judgment and then determines emotion. In the intuitionist model, on the contrary, emotion affects judgment and then judgment forms reason. In the dual process model, which takes a neutral standing, reason and emotion affect judgment together. Nonetheless, all these three models are unidirectional. The traditional rationalist model works in the process of reason-judgment-emotion, the intuitionist model works in the process of emotion-judgment-reason, and the dual process model divorces reason and emotion, though it resorts to the joint work of reason and emotion on judgment. ${ }^{9}$

The neo-sentimentalist model holds the view that judgment about emotion interacts with reason, and the more recent constitutional model holds that judgment containing emotion interacts with reason. According to Mencius, the feeling of compassion is closer to the last model, with evaluation and judgment containing emotion that interacts internally with reason. The latter two models emphasize a dual-track interaction between reason and emotion, but the difference is that the former is the judgment about emotion while the latter is the judgment containing emotion. Confucianism is perhaps closer to the latter model.

From the perspective of moral origin, Mencius places the feeling of compassion at the beginning and posits it as the center of humanity that progresses from feeling to moral sensibility. Another question is whether compassion is one of the basic human feelings. Recent research in cross-cultural studies shows that basic human feelings fall in different categories, but they mainly include pleasure, sorrow, anger, surprise, disgust, and fear. ${ }^{10}$ If we expand the list, we can include the following basic feelings: joy, anger, contempt, contentment, disgust, embarrassment, excitement, fear, guilt, pride in achievement, relief, sadness, satisfaction, sensory pleasure, and shame. ${ }^{11}$ But a problem arises. Since compassion or sympathy is not included in these lists of the basic human feelings, how does it come to be the foundational moral feeling? Therefore, we need to further inquire how compassion becomes a kind of primary moral feeling. Much has been written on this subject in European and American moral psychology.

\footnotetext{
9 Jesse J. Prinz, “Constructive Sentimentalism: Legal and Political Implications,” in Passions and Emotions, ed. James E. Fleming, (New York and London: New York University Press, 2012), 3-10.

${ }^{10}$ Michael S Gazzaniga, Richard B. Ivry, and George R. Mangun, Cognitive Neuroscience-The Biology of the Mind (Beijing: China Light Industry Press, 2003), 317.

${ }^{11}$ Paul Ekman, "Basic Emotions," in The Handbook of Cognition and Emotion, eds. T. Dalgleish and T. Power, (New York: Wiley, 1999), 45-60.
} 


\section{Moral Feeling: The Order and the Correlation Among the Four Sources of Morality}

What is the relationship between the feeling of compassion and the other components of Mencian morality? What is the correlation holding among the Four Original Sources or the Four Minds? Wu Yi 吴怡 gives a vivid description,

Humanity is the [center of] human mind and righteousness is the path [leading humanity] from inside the human mind to the outside. Propriety is the door [or gateway that censors it] from the inside to the outside, and knowledge is the [opening of] door [or gate] as well as the formation of judgment of [external] things. Thus, benevolence, righteousness, propriety, and knowledge form the sequence of the externalization of human emotions, progressing step by step to the outside and growing hardened in the process. ${ }^{12}$

I think this dynamic view of the four virtues is a closer understanding of Mencius's thought, as is illustrated below:

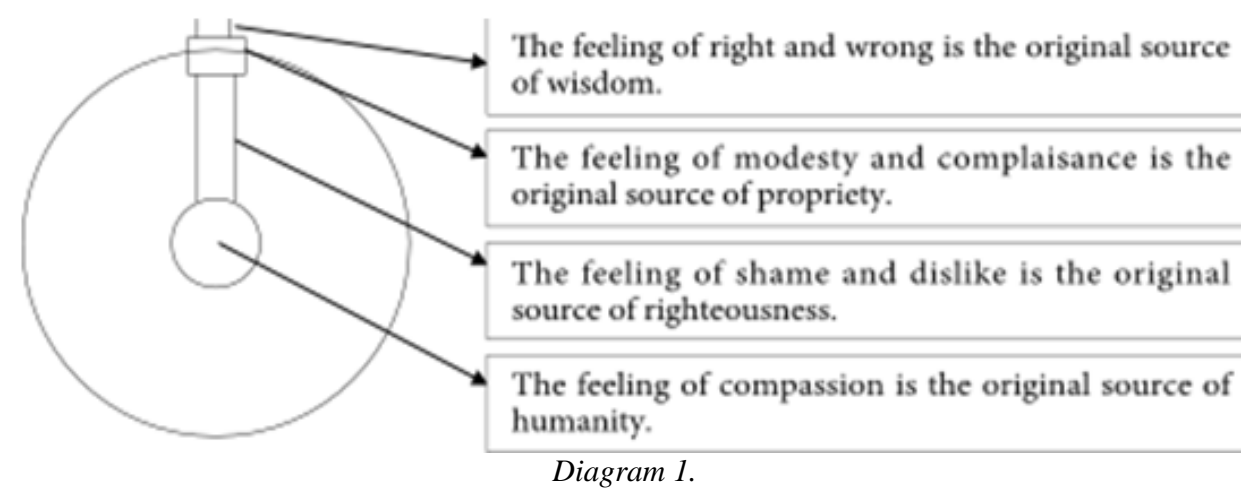

There should be a hierarchy and order in the unfolding of moral virtues of humanity, righteousness, propriety, and wisdom just like the inner procedure for moral feelings. Zhu Xi 朱喜 (1130-1200) gave his elucidation quite early:

Before Four Virtues start to work, though still and motionless, there are principles and orderly structures within, and it is not true that there is nothing within. So, when external [events] start [to stimulate] the sense [of principles], the internal [virtue] responds in time. ${ }^{13}$

This is just the case of "a child about to fall into a well," when the virtue of humanity is stimulated, the feeling of compassion responds. Similarly, in the case of "walking by a temple and the court,"14 when the virtue of propriety is stimulated, the feelings of reverence and respect respond. Zhu Xi further stated,

There exist all the principles within, each in proper order; therefore, the internal [principle] responds to the [different] external stimuli, and the Four Virtues of Humanity manifest themselves in different forms. Mencius divides them into four categories to explain to scholars that in the [seemingly indivisible] wholeness there are orderly principles and structures so as to help scholars better understand the goodness of human nature. ${ }^{15}$

According to Zhu's understanding and interpretation, the four moral virtues in their unarticulated form have their own inner structures and principles and should not be identified as an indiscriminate whole.

\footnotetext{
${ }^{12} \mathrm{Wu}$ Yi, Zhongguo zhexue fazhanshi 中国哲学发展史 [A Developmental History of Chinese Philosophy] (Taipei: San Min Book Co., Ltd, 2009), 106.

13 “Da Chen Qizhi” 答陈器之 [A Reply to Chen Qizhi], in Zhuxi ji 朱喜集 [Selected Works of Zhu Xi], vol. 58.

14 Ibid. Translator's note: Temples and courts, as religious and government abodes, are both solemn places to be held in awe.

15 Ibid.
} 
Although not identical, they are all the products of internal response to external influences. However, Zhu Xi differs with Mencius in the following: Zhu Xi explains the four moral virtues from the external to the internal (that is, external influence brings about internal change) while Mencius prescribes the Four Virtues from internal to external (that is, the internal feelings induce their external articulation). In addition, Mencius does not make a dichotomy of the articulated and un-articulated forms of these virtues.

It is without doubt that each of the four moral virtues varies in its articulation, but what is the internal logic for them to express themselves? Zhu Xi continues with his explication,

As humanity, righteousness, propriety, and wisdom are known to be clearly delineated, it is also necessary to know that of the four, humanity and righteousness are the key concepts for the demarcation. Humanity stands by itself but it is [codified and] preserved with ritual propriety; righteousness stands by itself but it is [rationalized into and] stored in knowledge is hidden in it. ${ }^{16}$

It can be seen that Zhu Xi makes a re-division of humanity, righteousness, propriety, and knowledge into two pairs: humanity goes with propriety, for it is externalized in the form of ritual; righteousness goes with knowledge and it is stored in [the repertoire of] knowledge. Finally, Zhu Xi encompasses all four in benevolence:

Although humanity and righteousness can stand on their own as two virtues, benevolence in fact runs through all the four. In its specific sense, it is one thing, but in its general sense, it is inclusive and pervades all four virtues. Thus, humanity is the substance, propriety is the ritual codification of humanity, righteousness is the well judged decision of humanity, and wisdom is the [judicious] discernment by benevolence. ${ }^{17}$

This view of benevolence as the highest virtue of all Four Virtues of Humanity represents the center of Zhu Xi's Renxue (the doctrine of humanity). He compares the respective importance of humanity, righteousness, propriety, and wisdom to the cyclic seasons of spring, summer, autumn, and winter. Humanity is like spring, which is the birth of spring [humanity itself]; righteousness is like summer which witnesses the growth of spring's humanity [into righteousness]; propriety is like the fall, which bears the maturity of spring's humanity to ripeness [ritual propriety according to humanity]; and wisdom is like winter, a season of preserving the autumn harvest of spring's benevolence [its seed to be preserved in knowledge]. Thus, everything starts with spring, as benevolence develops through all four moral virtues. Humanity gives expression to the four moral virtues with wisdom as the final product, to be preserved or stored in winter.

In this analogy of the four moral virtues to the cycle of four seasons, however, Zhu Xi seems to forget that spring succeeds to winter, too, whereas humanity cannot originate from wisdom just as feeling cannot originate from reason. In addition, it is hard to tell whether humanity must match with ritual propriety or righteousness must match with humanity. Compassion is perhaps closer to shame and dislike due to their emotional orientation; it is perhaps more appropriate for feelings of reverence and respect, as well as wisdom, to be grouped closer to reason. In other words, it is perhaps more appropriate for humanity to match with righteousness and for propriety to match with wisdom. Anyway, Mencius's humanity, righteousness, propriety, and wisdom in the sequence exactly follow the natural order of spring, summer, autumn, and winter.

From the perspective of their psychological origins, compassion can be considered as the fountainhead origin of the four moral virtues; however, to attribute everything to humanity seems to be a philosophical endeavor for metaphysics. Huang Zongxi 黄宗羲 (1610-1695) gives a different metaphor for them. He says:

\footnotetext{
${ }^{16}$ Ibid.

17 Ibid.
} 
Compassion is the germ of human nature; reverence and respect are the growth of human nature; shame and dislike are the harvest of human nature; right and wrong are the storage of human nature. The four virtues interact with and keep in balance with one another: there is restraint in promoting, and promoting in restraint; there is preservation/concealment in germination/expression, and germination/expression in preservation/concealment. ${ }^{18}$

However, these four original sources of morality are not on equal footing in their relationship of embracing one another. Compassion as the "naissance" of human nature is the most original of primary human tendencies because "the primary human propensity is the truest nature, coming from thoughtlessness and disinterestedness, that is its natural inclination; Contrarily, if we give a second thought to doing something, the decision is a result of deliberation and purposeful. What occurs to one's mind at the first instant is the primary thought. Whatever follows are all second thoughts. ${ }^{, 19}$ This distinction of the notion of compassion is no doubt judicious and to the point.

In fact, the closest feelings to that of compassion are shame and dislike. As far as basic human (not animal) emotions are concerned, the sense of shame and dislike [disdain] is more basic than that of sympathy. However, Mencius takes a biological perspective and considers compassion as the most essential human feelings of all, whereas Christian ethics tends to regard shame and dislike as the most essential. This is relatively true in view of the Biblical story about Adam and Eve eating the forbidden fruit. Nevertheless, the Chinese concept of shame and disdain cannot be taken to correspond to the Western sense of shame and humiliation (much as the same colors serve as different signifiers in the two cultures). Western shame-based culture of Christianity starts with the affection between men and women and then extends to other emotions, while the Chinese concept of shame and dislike is often derived from a self-conscious failure to attain a higher moral expectation. These distinctions aside, we still have the question: Can the feeling of shame and disdain be developed from compassion?

Psychologically, the sense of sympathy and that of shame and disdain are different in that one is internally originated and the other externally related. Mencius's compassion (as a species of sympathy) arises from within, and it is not for showing off to others. In other words, compassion is "[what] I [whisper] to myself," as is explained by Mencius: "It is not to be known to neighbors and friends, and not because one would dislike the sound of the child's cries” (Mencius, 2A: 6). On the other hand, the feeling of shame and disdain is different from compassion in that one would fear one's shame or disdain being perceived by others, which suggests a relationship of "others-to-me," or "me-to-others," when one feels shame or disdain.

From shame comes righteousness. Lee Yearly argues that,

Righteousness is both a virtue, a special human quality and it also refers to the action of this quality. However, Mencius's top priority is action. For example, he mentions some deeds that cannot be done for the sake of righteousness and some deeds that cannot be tolerated for the sake of benevolence. Righteousness comes from shame and dislike. ${ }^{20}$

However, this does not mean that Mencius, in his mature stage, has accepted the formulaic argument of humanity-within and righteousness-without, but it is true that the sense of shame and dislike is more likely to prompt action than is compassion. Conversely, the moral motive of compassion is indeed stronger but cannot be extended to shame or disdain, as each is an independent moral end. Compassion is a biologically

\footnotetext{
${ }^{18}$ Huang Zongxi, Mengzi shi shuo 孟子师说 [Mencius’s Teachings], vol. 2.

19 Ibid.

${ }^{20}$ Lee H. Yearley, Mencius and Aquinas: Theories of Virtue and Conceptions of Courage, trans. Shi Zhonglian, (Beijing: China Social Sciences Press, 2011), 45.
} 
instinct-driven feeling while the sense of shame and disdain is cultivated, whether it is a self-induced shame or disdain for others. ${ }^{21}$

Similar to the feeling of shame and dislike, the feeling of reverence and respect is also externally related and interactions of either a "me-to-others" or of "others-to-me" relationship. However, if the feeling of shame and dislike is more associated with one's emotions, then the feeling of reverence and respect shows more association with one's reason. The feeling of shame and dislike tends to be motive driven while the feeling of reverence and respect tends to be action driven. This contrast is like that between the feeling of compassion and the feeling of shame and dislike. Of course, there can be connection between the feeling of sympathy and the feeling of reverence and respect, but this connection will be contingent. The feeling of reverence and respect is not solely based on sympathy. For example, to offer something to others when they need it (like the story of Kong Rong offering his pear 孔融让梨) is not necessarily to sympathize with the recipient (like offering alms to beggars).

The feeling of reverence and respect can be psychologically but not necessarily based on the feeling of shame and dislike, for even if one does not have a feeling of reverence and respect, one may feel shame. Fair to say, this cannot be generalized to all moral situations. Objectively, the feeling of reverence and respect must be directed at a target (but the target for the feeling of shame and dislike may be contextualized), and the reverential or respectful person expects interaction with whomever/whatever he esteems. Subjectively, it is a morality-motivated feeling (but not as strongly motivated as compassion). The feeling of reverence and respect is more often categorized as "friendship" in Greek ethics, but in China, both inside and outside of the home, the feeling of reverence and respect has long been upheld as a virtue in mainstream ethics.

In contrast to the first three original sources, the feeling of right and wrong undoubtedly attains the highest level of moral cognition, for moral judgment bears greatly on it. In other words, the feeling of right and wrong is a state of the mind (xin) being conscious of one's own being; the feeling of shame and dislike and the feeling of reverence and respect are the mind being conscious of others; compassion is the mind in its self-consciousness. The feeling of right and wrong as moral judgment transcends the I vs. other relation, but still arises with the self.

From self-consciousness to consciousness of others, and then to consciousness of the self-being, there is a procedure and inner logic in the development, which can be traced. However, the four feelings do not relate to each other in an interlocking or progressive manner. Compassion cannot be extended to the feeling of shame and dislike, which in turn cannot be completely extended to the feeling of reverence and respect (it can only be partially extended), and there is a logical breach in moving between the feeling of reverence-respect and the feeling of right and wrong. Nonetheless, the four of them surely develop in an ascending order. Seen either as siduan or sixin, these essential moral feelings are moral virtues and they all start with compassion, advance through shame and dislike, reverence and respect, and finally reach the judgment of approval and disapproval.

The moral correlation holding among humanity, righteousness, propriety, and wisdom is more complex than can be explicated here. Zhu Xi made a focused study on the correlation between wisdom and the other three feelings and virtues, and he said, "Wisdom suggests a meaning of keeping storage as well as that of

\footnotetext{
${ }^{21}$ In modern research of psychological experiment, shame and guilt are both induced by the self; disgust and like are induced by the other; and hope and doubt are induced by the environment. I. J. Roseman, "Cognitive Determinants of Emotions: A Structural Theory,” in Review of Personality and Social PsychologyEmotions 5: Relationships and Health, ed. P. Shaver, (Beverly Hill: Sage, 1984), 31.
} 
ending and beginning"; "In fact, there is much to be done with the feelings of compassion, shame and dislike, and reverence and respect; but there is little to be done with wisdom"; "The feeling of compassion, the feeling of shame and dislike, and the feeling of reverence and respect all serve to expound a one-sided argument while the mind of right and wrong has to deal with two-sided arguments: both to justify one's approval and to spell out one's disapproval” (Selected Works of Zhu Xi, "Reply to Chen Qizhi”). Wisdom is apparently distant from humanity, yet it is quite similar to righteousness in some aspects, and righteousness has only propriety to match with. The correlation among the four feelings is indeed complicated:

Both righteousness and wisdom concern the judgment of action. However, wisdom may only discern the behavior while righteousness always needs the impulse to take action. ... Thanks to wisdom, the attitude of disapproval is most obvious; however, if there is no need for the impulse to take action, the emotional response like shame and disgust will not consequently appear. ${ }^{22}$

In fact, even if there is some element of moral judgment in righteousness, it is something that appeals strongly to moral impulses. In this sense, it is similar to the moral judgment of right and wrong but not identical to wisdom. Wisdom, inclusive of both beginning and ending, autonomous with nothing to be done, and rounded by two-sided considerations of both approval and disapproval, finally opens a gate of access to Mencius’s doctrine of ethics.

\section{Positive Feeling: The Goodness of Feeling Based on the Goodness of Human Nature}

It is generally accepted that Mencius's ideas on moral feeling are based on his theory that human nature is inherently good. Questions remains about the extent to which Mencius's basic notion of the inherent goodness of human nature bears on his ideas about feelings. There are certainly feelings of virtue and feelings of vice, but why does Mencius talk only positive feelings when he advocates feelings such as compassion? Conversely, why does Mencius remain silence on those negative feelings, as driven by desire?

In Western philosophy of emotion, a division exists between positive emotions and negative emotions. This division is not the kind of practical instrument employed in experimental psychology for psychological analysis. Richard Wollheim (1923-2003) has made some critical comment on this issue, saying that emotions fall into two series:

One sets out from the satisfaction of desire, and standardly terminates on what is called a positive emotion, or an emotion associated with pleasure, such as gratitude, joy, hope, love: the other sets out from the frustration of desire, and standardly terminates on what is called a negative emotion, or an emotion associated with displeasure, such as grief, hatred, anger. However, since it is far from clear that satisfaction and frustration are natural correlatives-for surely frustration is a far more complex notion-from now on. ${ }^{23}$

As can be seen from above, in Western philosophy of emotion, positive and negative feelings are differentiated by whether desire can be satisfied or not. That said, the question remains: Is a feeling still positive if bad desires pertaining to it are satisfied? We tend to determine the two aspects of emotion from the perspective of moral evaluation. Feelings are considered to be positive if lead to moral elevation, regardless whether they conform to or suppress desire, and vice versa. In this sense, Mencius is an ethicist who advocates positive feelings.

\footnotetext{
${ }^{22}$ Lee H. Yearley, Mencius and Aquinas: Theories of Virtue and Conceptions of Courage, 45.

${ }^{23}$ Richard Wollheim, "The Emotions and Their Philosophy of Mind," in Philosophy and the Emotions, ed. Anthony Hatsimoysis, (Cambridge: Cambridge University Press, 2003), 30.
} 
Let us first examine the explication of this position by Neo-Confucians of the Song and Ming dynasties. Zhu Xi gives his own commentary on Mencius's ideas on moral feeling:

The feelings of compassion, shame and dislike, reverence and respect, and right and wrong are human feelings (qing 情); humanity, righteousness, propriety, and wisdom are human nature (xing 性). The heart-mind (xin 心) is what governs both human nature and feelings. Duan 端 means “clues" or "sprouts" of things in their beginning. Once a feeling is revealed externally, the internal human nature is peeping out, and it is akin to something hidden in giving clue to its presence. (Collected Commentaries on Mencius, vol. 3)

Zhu Xi's view is debted to Zhang Zai's 张载 (1020-1077) view of "the mind (xin) as governor of human nature and feeling," and he employs a trichotomy of feeling, human nature, and mind. According to him, compassion is a feeling, humanity is human nature, and [the virtue of] compassion is [a faculty of] mind. He affirms that compassion is the original source of humanity and surely it fits Mencius's intended usage of the term, but Zhu Xi further believes that this kind of feeling, as the "sprout" of humanity, is the clue to human nature, which implies that there is more to be said about it. The unsaid part of Zhu Xi's commentary seems to suggest this: Since humanity, righteousness, propriety, and knowledge are part of human nature which constitutes the principles (li 理) of morality, therefore they are virtuous. In contrast, compassion is a feeling but the feeling of compassion comes through the mind and therefore, it seems to be capable of evil as well as good, whether mind is regarded as $q i$ 气 (vital energy) or conforms to principles and vital energy. In comparison, Cheng Yi 程卧 (1033-1107) first affirms human nature as the principle of virtue and then posits both the mind and feelings as derivatives (or consequences) of human nature. "Human nature, when taking form, is the mind; and when stirred, is feeling." ${ }^{24}$ This is different from Zhu Xi's view.

This expands the question to that of the mind. Then what is the relationship between the virtue of the mind and the virtue of human nature? In Mencius's view, the mind is inherently virtuous and therefore human nature is inherently virtuous, for the mind with the Four Original Sources of morality is inherently virtuous, and therefore human nature is virtuous. This seems to have reversed Mencius's view. Both Cheng Yi and Zhu Xi have over-expounded Mencius's thought, and yet Mencius does not seem to have explicitly stated the matter of a virtuous mind. In fact, what is worth noticing also includes the question of virtuous human nature or virtuous feeling.

In the Zhuzi yu lei 朱子语类 [Classified Utterances of Zhu Xi], there is a dialog of questions and answers: Question: "Mencius says that feeling and talent/ability are both virtuous. Why?” Reply: "Feeling is virtuous in nature and is not contaminated when unstirred, so why should it not be virtuous? Talent is only a natural gift, so there is nothing unvirtuous about it. These are like fabric of white color, which would remain white before being dyed with color" (vol. 59, chapter 9). This dialog suggests that according to Zhu Xi's interpretation, not only is human nature virtuous but also is feeling virtuous, and even talent is virtuous. Chen Li 陈澧 (1810-1882) in the Qing dynasty made a similar comment but focused on feeling and desire: "To talk about the goodness of human nature but not the evil aspect of feeling, this is in conformity to Mencius's tenet of the goodness of feeling. But, if we talk about desires, there can be virtuous desires as well as evil ones, and not all evils." ${ }^{25}$ As a result, Mencius's view of feeling as virtuous is considered to be his definitive conclusion of the issue. Since desires can be virtuous or evil, then emotional desires, according to Mencius's doctrine, naturally tends to be virtuous.

\footnotetext{
${ }^{24}$ Ercheng yishu 二程遗书 [Posthumous Writings of the Two Chengs], vol. 25.

${ }^{25}$ Chen Li, “Mencius,” in Dongshu dushu ji 东塾读书记 [Reading Notes at the East School], vol. 3.
} 
Another Confucian master of Mencius's status Xunzi (ca. 310-235 B.C.) held human nature to be inherently bad. Even so, evil in its philosophic sense is not considered as a property opposite to virtue. In Confucian canonical texts, there is no such concept as absolute evil or basic sin like those discussed in Western philosophy. To think of virtue and evil as independent qualities in opposition to each other is a Western dichotomy of concepts. In reality, there is no clear boundary between virtue and evil; instead, there is an obscure area that is neither virtuous nor evil. This means that when Mencius speaks of the non-virtuous, he is actually talking of the inefficiency of virtue, or lack of it:

What Mencius means by "evil" [not virtuous] is not a positive definition of evil but only a negative way of defining the concept. He imagines evil as something that has been reduced from a quality of existence but not something to be added. It is a kind of loss, something that does not exist but should have existed. ${ }^{26}$

If evil as Mencius sees it is a concept defined negatively, the virtues that he discusses are no doubt positive concepts. From his concept of human nature as virtuous, generally speaking, Mencius regards feeling as something positive, and therefore it is virtuous. Not only is human nature virtuous, but also is feeling virtuous. Compassion, which Mencius sees as a moral sentiment, is typically a positive feeling; the feeling of shame and dislike can also transform into moral motivation though it is a negative feeling.

This is important to the interpretation of one of Mencius's statements, that "feeling as such can be virtuous” [Nai ruo qi qing ze keyi weishan yi 乃若其情则可以为善矣] (Mencius, 6A: 6). If feeling is part of human nature, then not only is human nature virtuous but also is feeling virtuous; if feeling is a separate reality, then only human nature is virtuous, while feeling is indeterminate. The same is true of "feeling" as is used in the statement, "the Way begins from feelings" (dao shi yu qing 道始于情). ${ }^{27}$ Is this "feeling” used in the sense of the “reality of feeling” (qingshi 情实) or in the sense of “dispositional feeling” (qinggan 情感)?

Dai Zhen 戴震 (1724-1777) and Mou Zongsan 牟宗三 (1909-1995) put forward a reductionist view: Mencius's wording of qing 情 in nai ruo qi qing 乃若其情 (feeling as such) is not a feeling in contrast to one's natural xing, his natural inclination. Feeling in the other sense is feeling-in-itself, or something with its own reality. The determiner $q i$ 其 in nai ruo qi qing refers to xing (i.e., one's natural disposition). So, nai ruo qi qing refers to the part of the substance of human nature, or the original human disposition. As far as the original human nature is concerned, it makes people capable of virtuous deeds, and this is what I mean by human nature being virtuous. ${ }^{28}$ This being the case, from the fact of human nature being virtuous we can infer feeling to be virtuous, too, for from the positive definition of feeling, Mencius is largely inclined to the virtuous view of feeling.

Here is an observation by Zhao Qi 赵岐 (108-201) on the issue:

The word “ruo 若” in nai ruo qi qing means “to follow” or "be led by.” Human nature and feeling, so to speak, are two sides of the same coin. When virtuous human nature triumphs over feeling, feeling follows it. Feeling follows human nature, and who can make oneself virtuous by following his feeling is the truly virtuous. (Commentaries on Mencius)

\footnotetext{
${ }^{26}$ Maurizio Scarpari, “The Debate on Human Nature in Early Confucian Literature,” in Mencius’ Learning of Mental-Nature, 254. (Editor's note: This is a back translation, not a verbatim quote of the English text.)

27 “Xing zi ming chu” 性自命出 [Human Nature Comes from Destiny], in Guodian chujian 郭店楚简 [Guodian Chu Slips].

${ }^{28}$ Mou Zongsan, Xinti yu xingti 心体与性体 [Substance of Mind and Substance of Human Nature], book III (Taipei: Cheng Chung Book Co., Ltd., 1975), 416.
} 
Feeling follows human nature and therefore becomes virtuous. This can explain why Mencius, when commenting on "a child about to fall into a well," only considers the virtuous aspect to the exclusion of other aspects. When he discusses righteousness and propriety in specific situations, he presupposes that people could only do what they believe to be virtuous.

\section{What is the Global Value of Mencius's Thought on Moral Feeling?}

As Western philosophy, which has been "evergreen" since the time of ancient Greece, began to see a decline, global philosophy has been undergoing an intercultural turn. In this context, Mencius's philosophy is more than a regional one, but has global value. Mencius's wisdom, especially his ideas on feeling, could be revived internationally and its universal value could be widely appreciated and accepted in the foreseeable future. Nevertheless, even as universal value, it is not absolutist but retains its cultural distinction.

To attain that goal, we have to return to philosophical studies of human feelings. What role does feeling play in the structure of human nature? I hold the view that feeling plays a role at both the beginning and the end. By "beginning” I mean that "the Way begins with feeling," which is the fundamental structure of human nature. The "feeling" used here stands for not only a universal origin of a human state of mind but also a basic effect commonly shared by humanity. What I call the "end" is the goal, for example, to "seek the simple and virtuous life as Confucius and Yan Hui did” (Analects, 7:16). This is the ultimate pursuit by human beings based on the structure of human nature. However, this "simple and virtuous life" in the modern sense needs creative transformation by adopting scientific methods of viewing the world. The pursuit itself involves feeling, and it is not by way of the moral metaphysics prevailing from the Song Neo-Confucianism until Contemporary Confucianism, but by an aesthetic metaphysics that emphasizes human sentiments and feelings and the mode of human existence in harmony with the universe. This metaphysics is the historicized a priori structure derived from living experience. In this sense, Mencius's thought on moral feeling is more likely to develop into a token study of humanity.

Thus, we embrace the vision that in the future new trails may be blazed for dis-seminating Confucianism if we return to the study of the Confucian canons. More and more scholars today believe that the Confucian studies on xin and human nature are most likely to bring us closer to the ultimate goal. However, we have misgivings, just by reflecting on its history of research, that the conventional approach of high-sounding metaphysics will not hold much of its appeal against the backdrop of a general decline of Western metaphysics. Besides, as research on global ethics has been busy with "digging down” for the fundamental issues of ethics, the study of global value cannot seek for its object in mid-air, but should take a down-to-earth approach to the structure of human feeling and human reason.

To put it bluntly, this feeling-reason structure is in accordance with the principles of zhiliang 执两 (grasping the two poles of the beginning and the end) and yongzhong 用中 (employing the middle). From a practical point of view, all metaphysics come from mundane concerns: "the Way begins from feelings.” As for the advanced condition of existence, Confucius and Yan Hui's seeking "simple and virtuous life" is an ideal model. The principles of zhiliang and yongzhong are true wisdoms of Confucianism, which can be revived and globally applicable.

\section{References}

Behuniak, J., \& Ames, R. (2005). Mencius’ learning of mental-nature. (Liang Xi, Trans.). Beijing: China Social Sciences Press. 
Dalgleish, T., \& Power, T. (1999). The handbook of cognition and emotion. New York: Wiley.

Fleming, J. (2012). Passions and emotions. New York and London: New York University Press.

Gazzaniga M., Ivry, R., \& Mangun, G. (2003). Cognitive neuroscience-The biology of the mind. Beijing: China Light Industry Press.

Hatsimoysis, A. (2003). Philosophy and the emotions. Cambridge: Cambridge University Press.

Mencius. (2011). The works of Mencius. (J. Legge, Trans.). Beijing: Foreign Language Teaching and Research Press.

Mengzi. (2008). Mengzi: With selections from traditional commentaries. (B. W. Van Norden, Trans.). Indianapolis: Hackett Publishing.

Munro, D. (2005). A Chinese ethics for the new century. Hong Kong: The Chinese University Press.

Roseman, I. (1984). Cognitive determinants of emotions: A structural theory. In P. Shaver (Ed.), Review of personality and social psychology emotions 5: Relationships and health (pp. 11-36). Beverly Hill: Sage.

Solomon, R. (1993). Passions: Emotions and the meaning of life. Indianapolis: Hackett Publishing Company.

Waal, F. (2013). Primates and philosophers: How morality evolved. (Zhao Qianli, Trans.). Shanghai: Shanghai Science and Technology Education Press.

Yearley, L. (2011). Mencius and aquinas: Theories of virtue and conceptions of courage. (Shi Zhonglian, Trans.). Beijing: China Social Sciences Press.

Yi, W. (2009). Zhongguo zhexue fazhanshi 中国哲学发展史 [A developmental history of Chinese philosophy]. Taipei: San Min Book Co., Ltd.

Li, Z. H., \& Liu, Y. D. (2014). Guanyu “Qing ben ti” de zhongguo zhexue duihua 关于“情本体”的中国哲学对话 [A philosophical dialog on the “ontology of emotion”]. Journal of Literature, History and Philosophy 文史哲, 3, 18-29.

Mou, Z. S. (1975). Xinti yu xingti 心体与性体 [Substance of mind and substance of human nature]. Taipei: Cheng Chung Book Co., Ltd. 